\title{
READING ALOUD PERIODICALLY TOWARDS ENGLISH PRONUNCIATION OF NON-ENGLISH MAJOR STUDENTS
}

\author{
Dhanan Abimanto \\ Universitas Maritim AMNI Semarang \\ Email: dhananabimanto@gmail.com
}

\begin{abstract}
This research aims to know about the effectiveness of reading aloud periodically method in assisting the English pronunciation problem made by non-English major students. The objectives of tis research are (1) to know the effectiveness of the method and (2) to gauge the reason why the students have problem in English pronunciation. The researcher method used quasi-experimental research. The data was taken from first semester students of the non-English department (students of the Transportation study program). In analyzing the data, the researcher used two analyses, which are statistical analysis and non-statistical which is presented in descriptive discussion. Based on the data, the researcher found that in the pre-test, before giving the treatment, students still made some mistakes in English pronunciation. After giving the treatment, students showed the progress in their English pronunciation. There was an increase between the pre-test and the posttest about 21,33 in score or $\mathrm{t}$-test calculation, $\mathrm{t}$ count $>\mathrm{t}$ table $=10,718>3,12$ with $32,53 \%$ mispronunciation made by students after giving the treatments ten times. It showed that the method of reading aloud was effective to help in improving students' English pronunciation. Besides, the researcher found that the reason for students' problems in pronunciation after interviewing students was there is an interference of students' mother tongue, the familiarity to use English in daily activities and the influence of their habit reading the word in the Indonesian language.
\end{abstract}

\section{Keywords: reading aloud; story text; students' English pronunciation}

\section{INTRODUCTION}

Pronunciation is considered a field studied less than the other fields because of the difficulty. It is believed that pronunciation has many different variables that interfere with its process such as gender, motivation, field independence/dependence, etc. (Asher and Garcia in Çakır and Baytar, 2014). Due to the mother tongue, the foreign language learners find the problem to acquire the English pronunciation. It is supported by the habit of language learners who dwell in a country that does not make English as a first or second language, they rarely speak English in 
daily activity. For instance, Indonesian students may find difficulties in pronouncing some English words.

There are many ways to maintain the pronunciation, however, one of the ways is reading methods. This method, in some research, is believed to improve pronunciation by conducting aloud reading. Huang (2010) states that one of the reading aloud functions is practice pronunciation. By applying an aloud reading method in teaching reading to students, this is hoped to improve the English language learners' English pronunciation. Doff (2008) says that reading aloud involves seeing the text and comprehending it, and also saying it out. Even though reading aloud is believed as a method to deliver the needed information to others, however, it is the unpopular method done at the out-class learning. For language learners, reading aloud is rather than pronunciation practice. Besides, Doff states that reading aloud proves that it is useful for language learners since it helps language learners make a connection between sound and spelling words, and also helps them to check the learners' vocabularies. In addition, Nurani and Rosyada's research (2014) provides that reading aloud effectively affects the adult language learners' pronunciation. They added reading aloud method is a good method to increase the learners' motivation in learning pronunciation as a new experience.

According to Gilbert (2008), language learners still do not care about the importance of pronunciation. They still think that English is about grammar and vocabulary. As we know that pronunciation is also important in learning a language. Although English has been taught for years from primary school to university, students still make some mistakes in their English pronunciation. Pronouncing a word can be very difficult for Indonesian language learners due to the interference of their mother tongue. So, many learners of English have a foreign accent that identifies them as non-native speakers. For example, the word "pain", some learners will say [pain] not [pern] without changing the pronunciation of a letter "a" which is pronounced [er]. However, Jenkins in Hancock (2018) the goal of teaching pronunciation is not to sound like a native speaker, but rather to communicate effectively. Unfortunately, students who are not learning English as a major subject will be difficult to improve their pronunciation since they just get the subject only once a week. It will be another problem due to the time of learning a language.

As the statement above, it can be concluded that the method of reading aloud can be one of the methods to improve the student's skills such as pronunciation, intonation, and to enrich the vocabulary. Besides, the time of learning language is one of the problems to deepen English pronunciation learning. it can be said that the lesser time the students have, the less knowledge the students get. 
Therefore, this research compiles two research problems that becomes of the objective of it. (1) to know the effectiveness of reading aloud applied in teaching English in non-English major students towards students' pronunciation. (2) it is to gauge the reason why the students have problems in pronouncing English words although they have studied English for years.

\section{RESEARCH METHOD}

The population of this research is the first semester of non-English program students, i.e. Transportation program in the academic year 2019/2020. While the sample taken is purposive sampling where the sample is taken randomly and chosen for this research. The taken samples were 30 students who had low grades in reading English texts. Data was taken during "reading" learning during semester one.

This study uses a quasi-experimental method with non-equivalent groups where two groups are not randomly selected, then given a pre-test to determine the prior and after treatment. The experimental group was given ten treatments by giving a reading aloud method. The treatment given is reading English story texts aloud. The reading text given varies during the treatments. After that, the students were given a post-test to find out the results of the comparison before and after ten treatments. As an illustration, it is as in the following table.

Table 1. Research Design

\begin{tabular}{cccc}
\hline Group & Pretest & treatment 1 -10x & Post-test \\
\hline Experimental group & $\mathrm{O}_{1}$ & Reading aloud & $\mathrm{O}_{2}$ \\
\hline
\end{tabular}

At the end of the session, an interview was conducted with the experimental group to learn information about the learning process specifically the problem of learning English reading. Furthermore, the data that has been obtained by analysis using statistical tests and non-statistical analysis. The result of the statistical test, it will be presented in the form of calculation data, while for non-statistical data analysis will be presented in the form of a description containing the results of the interview.

\section{FINDINGS AND DISCUSSION}

The researcher conducted several calculations of the validity and reliability of the tests given, the results that emerged were as follows: the results of the validity and invalidity of the whole test of 0.467 where this was greater than r-table, while the reliability test of 0.91 was higher 
than the critical value of 0.361 from r-table. This means that the given test was following the reliability requirements.

Pronunciation errors made by students are calculated to find the percentage of errors in pronunciation. Expressed in the following table.

\section{Table 2. Percentage of mispronounced words made by students}

\begin{tabular}{cccc}
\hline No & E & T & Mispronounced words (\%) \\
\hline$\sum$ & $\mathbf{2 5 3 0}$ & $\mathbf{7 5 0}$ & $\mathbf{3 2 , 5 3}$
\end{tabular}

From the table above, the percentage of students' pronunciation problems is obtained by $32.53 \%$. Because the calculation result is $32.53 \%$. So, the percentage of pronunciation mistakes is categorized as low. Even though students can be categorized well, students still make mistakes, they still made a few words incorrectly.

While the scores on the given pre-test and post-test given before and after treatment are as follows.

Table 3. Calculations before and after treatment in the pre-test and post-test

\begin{tabular}{cccc}
\hline Note & Pretest & Post-test & Result (d) \\
& & Post-test - pretest \\
\hline Average & 84,33 & 105,67 & 21,33 \\
\hline
\end{tabular}

It can be seen that the pre-test results on 30 students before treatment obtained an average score of around 84.33. After giving treatments that asked students to read the story text containing some of the pronunciation words tested, the results of the post-test showed around 105.67. It shows that there is an increase in scores around 21, 33. It means that there is an increase in scores on students after giving treatment in reading aloud periodically. 
Table 4. Result of Paired Sample T-Test

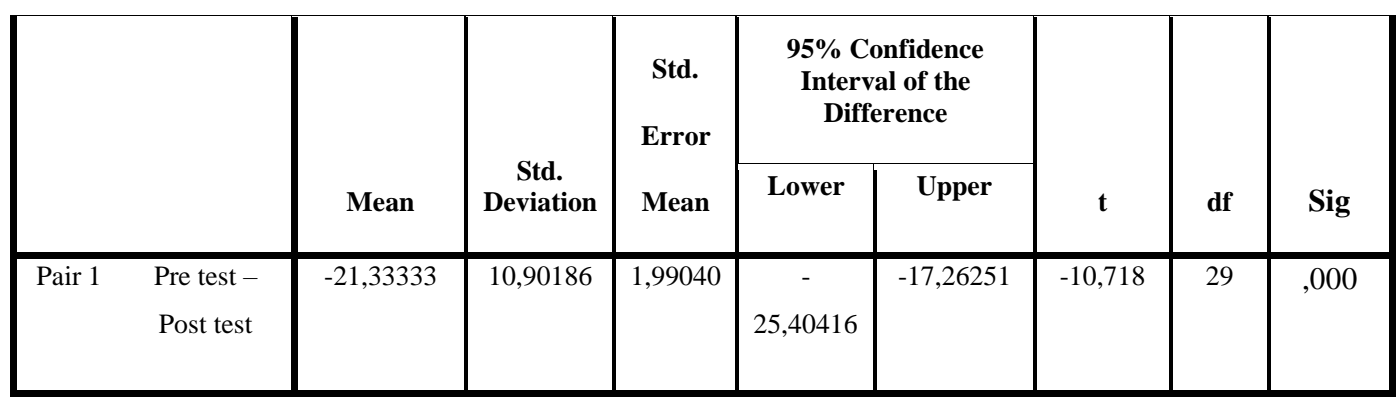

Based on the paired sample t-test above, it can be explained that the value of Sig is 0 , which $0<0,05$. It means that there is a difference between pre-test and post-test. if the value is compared with the $t$ table is 3,12 . The value indicates that $t$ count $>t$ table or 10,718>3,12; it indicates that the value is accepted which means there is an increase in value before and after treatment. In other words, reading aloud periodically method is more likely to improve students' pronunciation. It can be an effective way to improve and build good English pronunciation.

One of the aims of current research was to test the effectiveness of reading aloud to improve the pronunciation of students who are non-English major students. The result of the research revealed that reading aloud seems to be effective in improving students' pronunciation in line with other researches that have researched the same topic as the current research (Huang 2010; Nurani dan Rosyada 2015). The previous research has also revealed that reading aloud were also effective in improving language learners' pronunciation. In the research, students improved their pronunciation in categories: articulation, stress, and intonation. It is in accordance with Huang's statement (2010) that reading aloud is a very good pronunciation practice especially in practicing intonation, rhythm, and stress.

In this research, the researcher also got findings related to the pronunciation problems of students while giving the test. Students tend to pronounce English vocabulary incorrectly as a phenomenon above. Pronunciation errors are something that often happens. Some students missed the tested words given to them. For example: "Are you going here today?" which general pronunciation in American and British English pronounced as [/a:r/ /ju//'gəひ.In//hı(r)//tə//daI/], unfortunately, one student pronounced incorrectly: "are" /ar/ "you" /yu/ "going"/go-ing/ "here" /her/ "to" /tu/ "day" /dat/. Besides, cases of pronunciation errors like the example above often occur. Common error in English pronunciation that often occur in the research such as: "day" [deI] and "die" [dai]; "work" [wə: k] and "walk" [wo: k]; "snake" [sneik] and "snack" [snæk]; "other"

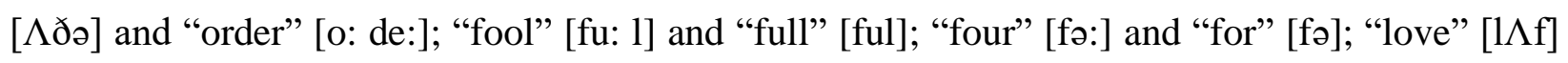


and "laugh" [laf]; "feel" [fi: 1] and "fill" [fil]; "high" [hai] and "hike" [haik]. This kind of error can be minimized by practicing every day by reading aloud as stated above.

Some words of English pronunciation are indeed different in several native speaker countries such as American English (AE) and British English (BE) pronunciation. For instance, the word "water" both $\mathrm{AE}$ and $\mathrm{BE}$ has the same phonetic transcription, but it is pronounced differently. BE pronunciation pronounces the word "water" as ['wo:tə(r)] with sound /wo/ which pronounce it like there is a long back rounded sound /o:/, which sounds like in "sword" [so:d] within it and sound /r/ pronounced silently, whereas in AE pronunciation, sound [wo] is pronounced like in "cot" [kat] and sound /r/ is pronounced.

In addition, as data found in this research the word "day" will be commonly pronounced [deI] both in AE and BE not [daI], whereas in Australia it will be pronounced [daI]. However, this pronunciation is acceptable because it may be related to the local accent. When the word pronunciation applies in non-native speaker country like Indonesia, it will be a misunderstanding word, due to the meaning is also different between "die" and "day". Hence, the pronunciation is more important when it is learned in a non-native speaker country. Therefore, knowing a proper pronunciation will help the listener to understand what the speaker says particularly knowing which sound is stressed. Lynch and Anderson (2012) even state that stress in pronunciation word is important because it reflects the meaning the speakers intend the listeners to understand.

The second aim of this research was to know a reason influencing students' pronunciation. according to the interview, the researcher can conclude that the pronunciation mistakes made by students are caused by the familiarity to use English in daily activities and the influence of their habit of reading words in Bahasa Indonesia, there is no difference between spelling and pronunciation in Indonesian as their mother tongue. They tend to say words in English like they use in Indonesian. It is in line with Dhillon (2016) that interference of learner's mother tongue affects the English pronunciation and made some learners difficult to pronounce some English phoneme.

Despite teaching pronunciation requires efforts to improve pronunciation of non-native English learners, particularly for EFL learners who are still have interference of mother tongue. Besides, pronunciation relating to the meaning of what the speaker wants to states. It would be a misunderstanding if non-native speaker pronounces an incorrect word. In the end, learning pronunciation is a needed skill to have in learning language especially for EFL learners although the pronunciation is native-like. 


\section{CONCLUSIONS}

Pronunciation as a sub-component of language skills is one of several serious problems faced by learners of English as a foreign language. By always taking the time to practice it, they can be closer to the right way to say English words.

Based on the research, it can be concluded that reading aloud which is given periodically to students of non- major English is effective. It is because there is difference in scores between pre-test and post-test. The result is very significant, there is an increase in the score of 21.33 , which $32,53 \%$ of mispronunciation. A comparison between pre-test and post-test is shown by the number of paired t-tests that $\mathrm{t}$ count $>\mathrm{t}$ table $=10,718>3,12$. It shows that there is an increase in value before and after ten times of treatments.

The mispronunciation made by students, according to the interview, is caused by the interference of the mother tongue of students, the Indonesian accent and local accent affect their English pronunciation. Besides, the familiarity of using English in their daily activities and the influence of their habit of reading words in Bahasa Indonesia affect the students' pronunciation.

\section{REFERENCES}

Çakır, İ., \& Baytar, B. (2014). JOURNAL OF LANGUAGE AND LINGUISTIC STUDIES Foreign language learners' views on the importance of learning the target language pronunciation. Journal of Language and Linguistic Studies, 10(1), 99-110. www.jlls.org

Chall, Jeanne S., and Stahl, Steven. (2008). Reading. Microsoft@ Student 2009 [DVD]. Redmond, WA: Microsoft Corporation.

Dhillon, B. (2016). Running Head: DOES MOTHER TONGUE AFFECT THE ENGLISH PRONUNCIATION? International Conference on Language, Education, Humanities and Innovation, 121-132.

Doff, A. (1988). Teach English: A Training Course for Teachers. Cambridge: Cambridge University Press.

Gilbert, J. (2008). Teaching pronunciation using the prosody pyramid. New York: Cambridge University Press

Hancock, M. (2018). Pronunciation in the English language classroom is more than just "listen and repeat." https://www.britishcouncil.org/voices-magazine/teaching-pronunciation-morejust-listen-and-repeat

Huang, L. (2010). Reading Aloud in the Foreign Language Teaching. Asian Social Science, 6(4), 148-150. https://doi.org/10.5539/ass.v6n4p148 
Lynch, T., Anderson, K., Language, E., \& Centre, T. (2012). EFFECTIVE ENGLISH LEARNING Unit 7 : Speaking. Effective English Learning, 1, 1-20.

Nurani, S., \& Rosyada, A. (2015). Improving English pronunciation of adult ESL learners. Lingua Cultura, 9(2), 108-113. 
